\title{
The Subjects That the Pre-service Classroom Teachers Perceive as Difficult in Elementary Mathematics Curriculum
}

\author{
Çiğdem İnci Kuzu*, Muhammed Celal Uras \\ Department of Mathematics and Science Education, Faculty of Education, Agri Ibrahim Cecen University, Turkey
}

Copyright $\bigcirc 2018$ by authors, all rights reserved. Authors agree that this article remains permanently open access under the terms of the Creative Commons Attribution License 4.0 International License

\begin{abstract}
OECD-PISA which evaluates the education quality of Europe focused on mathematics, and Turkey was ranked 50 among 72 countries. When the mathematics literacy was analyzed in terms of years, it is seen that the performance of the students in Turkey in PISA 2015 was lower compared to PISA 2009 and PISA 2012. This shows that students have difficulty in comprehending the subjects in the mathematics curriculum. Therefore, learning experiences designed for the pupils to have rich mathematics experiences during elementary school is of higher importance. At this point, it is necessary to know the subjects that the pre-service teachers, who will be teachers of the future, are challenged in teaching mathematics. Therefore, the purpose of study is to determine the subjects in which elementary school pre-service teachers perceive teaching in elementary school mathematics as difficult and to examine the causes of these difficulties. The case study method is used in this study and the participants of the study are 120 pre-service classroom teachers who study in the fourth grade in a state university. Participants were administered a 19-item learning difficulty index covering mathematics learning areas of $1-4$ grades $(n=120)$. The distribution of answers given by the pre-service teachers for each topic and the learning difficulty index for each topic were calculated. Interviews were done with the pre-service teachers in response to their responses to the questionnaire items to understand the causes of the difficulties. In interviews conducted one by one, the pre-service teachers were asked general mathematics lecture notes, mathematics fear level and the reasons for the topics they found difficult to teach.
\end{abstract}

Keywords Elementary Mathematics Curriculum, Difficult Subjects, Pre-Service Classroom Teachers

\section{Introduction}

Mathematics is a language in which people can communicate with each other through various means. However, mathematics is not only a language of communication or an effective tool that people in the world of science or certain people need. It is a need that everyone in daily life needs. It also has a very important role in maintaining the daily lives of individuals. Mathematics includes basic skills and compulsory knowledge as well as some skills that must be acquired for individuals in general and it is difficult for a student experiencing a learning disability, especially in the mathematical context, to succeed in the next issues [1,2].

In the past, in mathematics education, individuals were expected to perform at the highest level and be equipped with mathematical knowledge to keep themselves above other individuals. In recent years, there have been significant changes in the way we look at mathematics education. Nowadays, individuals need to acquire new mathematical identities by going beyond basic skills. With mathematics education, it is aimed to educate people who do not only know mathematics but also, they can apply mathematical knowledge, do mathematics and have problem solving skills. It is only possible to raise individuals who have developed mathematical literacy in this framework. Mathematical literacy focuses on measuring the capacity of students to formulate, use and interpret mathematics in different contexts [3]. Regarding the context above, the Ministry of National Education (MEB) prepared a report in 2016 emphasizing the necessity of using mathematical concepts, processes, facts and tools to develop mathematical reasoning, explanation and prediction by students who have developed mathematical literacy. In order to measure these skills, a study has been conducted by the Organization for Economic Co-operation and Development (OECD), under the name of the Programme for International Student Assessment (PISA), evaluating the knowledge and skills gained by students aged 15 years for over three years. The difficulties experienced by individuals who want to achieve these goals are seen as a fact of life [4,5] 
When the average scores in the field of PISA mathematics literacy are examined according to years, PISA 2015 performance of students in Turkey appears to be lower than in PISA 2009 and PISA 2012.

Table 1. Mathematical literacy averages according to years [3]

\begin{tabular}{|c|c|c|c|}
\hline & PISA 2015 & $\begin{array}{l}\text { PISA } \\
2012\end{array}$ & $\begin{array}{c}\text { PISA } \\
2009\end{array}$ \\
\hline OECD Average & 490 & 494 & 496 \\
\hline All Countries Average & 461 & 470 & 465 \\
\hline Turkey Average & 420 & 448 & 445 \\
\hline Ranking & 50 & 44 & 41 \\
\hline $\begin{array}{c}\text { Number of Participating } \\
\text { Countries }\end{array}$ & 72 & 65 & 65 \\
\hline
\end{tabular}

The acquisition and development of skills such as problem solving, reasoning, judging, finding solutions, associating and representing skills through mathematics is a recognized reality today. The basis for the achievement of these skills and the formation of mathematical identities begins from the very beginning of the educational life of individuals. This stage for pupils at basic education level is of critical importance. The biggest task is laid to the classroom teachers so that this critical stage can be completed as desired. In addition, mathematics education studies have shown that the chosen approach and strategy, techniques and methods used in the learning-teaching process, classroom relations and the activities that are fostered have very different results in the acquisition of knowledge and skills of the students [6]. One of the factors that has a significant share in shaping these results is the pedagogical field knowledge first introduced by Shulman [7]. Shulman's pedagogical field knowledge, known for his work in the field of "teaching knowledge" $[7,8]$, is a combination of knowledge and pedagogical knowledge of a field and in this respect, it is expressed as the accumulation of knowledge that distinguishes an educator from the subject specialist [9].

Shulman [7] describes pedagogical field knowledge more specifically as the most useful representations of content, the most effective analogies, the pictures and examples, the forms of representation and teaching that make the subject understandable to others. It can be said that the concept of "pedagogical field knowledge", which is frequently used in the general education and field education literature, has a practical value as the teachers try to explain the information they need to learn about the learning process of the students or to learn better [9].

Field knowledge is important in mathematics to combine conceptual and operational performance. Ball [10] emphasized that in this context, a teacher should have both knowledge of mathematics and knowledge about the mathematics. The important point in this kind of information is the teacher's level of understanding the mathematics. According to Ball [11], in addition to the conceptual and operational knowledge that teachers have, they also need to understand the underlying principles of this knowledge. Pedagogical field knowledge, which is another type of knowledge the teacher should have, also depends on his field knowledge [12].

It is clear that the pedagogical field knowledge of teachers is of higher importance in implementing the new programs successfully considering that the curriculums implemented highlight conceptual meaning and that has an approach based on establishing relationships among the concepts and thus acquiring learning experiences. It is also likely that there are a number of learning difficulties and failures in the learning process of the students and the activities they attend. Identification and elimination of such situations, assisting and guiding the student in the learning process are among the primary tasks of the teacher. In this context, it is necessary for the pre-service classroom teachers and classroom teachers to have pedagogical field knowledge in order to be able to carry out the curriculum effectively. It is obvious that if the pedagogical field knowledge that the teachers have is inadequate or insufficient, the teachers will have difficulty in expressing the topics and the efficiency of the teaching program will decrease $[13,14]$.

\section{Problematic Sentence}

The problematic sentence of the study is "What are the subjects that the pre-service classroom teachers perceive as difficult in elementary 1-4 grade mathematics curriculum?"

\section{Materials and Methods}

Case study is used in this study. This research method gives an opportunity to concentrate on a specified topic or situation. It also allows the use of quantitative and qualitative techniques and does not aim to generalize [15]. In this study, the opinions of the students in the department of classroom teaching about the subjects in which they are challenged in the teaching mathematics subjects were collected as quantitative data and the opinions of the pre-service classroom teachers about the subjects that students in the mathematics lessons were challenged were collected as qualitative data. The results obtained here are limited to this study group and there is no generalization purpose, because the mathematics level of the study group is quite low. For these reasons, it was decided to use the case study method for this research. The research was carried out in the academic year of 2017-20018 and the survey was applied to 120 randomly selected pre-service teachers who were educated in the department of classroom teaching, faculty of the education. Pre-service classroom teachers took General Mathematics 1 and General Mathematics 2 lessons for two hours a week in the $1^{\text {st }}$ grade, and they took Teaching Mathematics 1 and Teaching Mathematics 2 lesson for 
three hours a week in the $3^{\text {rd }}$ grade.

\subsection{Data Collection Tools}

As a data collection tool, a questionnaire protocol was prepared to be applied to the pre-service classroom teachers and an interview was also held with pre-service teachers. In this questionnaire, there are totally 19 sub-learning fields including topics in 1-4 grade elementary mathematics curriculum. There are 4 different options for these topics: "Easy to explain", "Difficult to explain", "Cannot tell" and "No knowledge" and the pre-service teachers were asked to mark the appropriate option for each sub-learning field. In addition, interviews were conducted with the pre-service teachers to understand the causes of the difficulties occurred as a result of the responses given to the questionnaire items. In the interviews conducted one by one, the pre-service teachers were asked general mathematics lecture notes, mathematics fear level and the reasons for the topics they found difficult to teach.

\subsection{Data Collection Process and Data Analysis}

The answers of the pre-service classroom teachers to the 19-item questionnaire are graded as following "Easy to teach", "Difficult to teach", "Cannot teach" and "No knowledge" and the pre-service teachers are asked to evaluate these sub-learning fields according to the difficulty levels of their learning. The following formula is used to calculate the difficulty index for each subject [16]. This formula, which is used to calculate difficulty levels, has also been used in some studies [17]. Then, Cannot teach (C)- Difficult but can be taught (B) are added and indicated as "Difficult", Easy to teach (A) as "Easy", No knowledge (D) as "Not sure."

$$
\text { Difficulty level }=\frac{N_{d} * 100}{N_{t}-N_{n}}
$$

$\mathrm{Nt}=$ Total number of the students participating in the questionnaire

$\mathrm{N} n=$ The number of the students who haven't learnt the subject

$\mathrm{Nd}=$ The number of the students who find the subject difficult

Frequency and percentages of the pre-service teachers for the sub-learning fields in the mathematics curriculum were calculated. In the analysis of quantitative data, frequencies and percentages of each item are calculated and presented in tables. Semi-structured interviews were conducted with pre-service classroom teachers to determine the most challenging topics in teaching mathematics. The opinions of the pre-service teachers were taken in black and white for these interviews. The opinions of the pre-service teachers were reviewed and checked again after written interviews, so that the misunderstandings of the audience were removed. The answers given by the pre-service teachers were obtained as qualitative data. In the analysis of qualitative data, a method of expressing in terms of percentages is used. Because the percentage calculations that take an important place in the systematic quantification of observation or interview data are among the most commonly used data analysis and presentation methods in qualitative researches [18].

\section{Findings}

In this section, the findings of questionnaire and interview applied to pre-service teachers to determine the sub-learning areas that are the most difficult for pre-service classroom teachers in 1-4 grade mathematics teaching are presented. In this context, under the heading of; 'What are the subjects that the pre-service classroom teachers perceive as difficult in elementary mathematics curriculum?' the views of the pre-service classroom teachers about the sub-learning fields (SLF) that they have difficulty in the Elementary Mathematics Curriculum are presented. The distribution for the answers of the students to each subject and learning difficulty index were calculated and presented in tables. A indicates the number of students who stated that they can teach easy, B indicates the number of students who have difficulty but can teach, $\mathrm{C}$ indicates the number of students who cannot teach, and $\mathrm{D}$ indicates the number of students who have no knowledge on the table.

It was determined in Table 2 that difficulty index of the natural numbers and addition of natural numbers sub-learning fields is $2.5 \%$. In addition, it was found that the difficulty index of multiplication of natural number sub-learning field is above $53 \%$. In the interviews, the pre-service teachers expressed that the reason why they have difficulty in teaching the multiplication is lack of practice, that they cannot teach it in a way that is appropriate to the student level and that they'll have difficulty in embodying the subject. Among the subject that the pre-service teachers have difficulty the most is the subtraction of natural numbers with a percentage of above $84 \%$. The pre-service teachers expressed the same reasons as the multiplication for the reason of this, particularly in embodying the subject. "Fraction" with a percentage of $84.6 \%$ and "Fraction operations" with a percentage of $92.3 \%$ come to the foreground as the subjects with the highest difficulty index. The reason why they think they'll have difficulty in fractions is that most of them think the students will have difficulty in perceiving the subject as they meet this subject for the first time, that the subjects are interrelated, that reading is not enough for success, that reasoning is compulsory, that operations take time, that having lack of time in reinforcing the subjects. The pre-service teachers also expressed that they have difficulty in fraction operation 
themselves therefore they'll have difficulty in teaching them.

It was determined in Table 3 that item difficulty index of geometric figures and objects sub-learning fields is $25.6 \%$. In addition, item difficulty index of spatial relationships is above $65 \%$, item difficulty index of geometric patterns is calculated as $56.4 \%$, and item difficulty index of basic concepts in geometry is calculated as $45 \%$. The reason why the pre-service teachers consider this field difficult is that the subjects are abstract and their lack of knowledge about the field.

It was determined in Table 4 that item difficulty index of our money sub-learning field is below 5\%, item difficulty index of length measurement is $40 \%$, item difficulty index of perimetry is $35.8 \%$, item difficulty index of time measurement is $25.6 \%$, item difficulty index of weighing is below $24 \%$. It was also determined that among the subject that the pre-service teachers have difficulty the most are the square measurement with a percentage of $57.8 \%$ difficulty index and liquid measurement with a percentage of $52.9 \%$. The main reason why they have difficulty in these subjects is the lack of knowledge, as expressed by the pre-service teachers. They stated that they will not be able to teach a subject which they do not know themselves, file to us for reproduction.

Table 2. Difficulty Percentages in the Views of the Pre-service Classroom Teachers related to the Numbers and Operations SLF

\begin{tabular}{|c|c|c|c|c|c|c|c|c|c|}
\hline \multirow{2}{*}{ Sub-learning field (SLF) } & \multicolumn{2}{|c|}{$\mathbf{A}$} & \multicolumn{2}{|c|}{ B } & $\mathbf{C}$ & \multicolumn{3}{|c|}{ D } & \multirow{2}{*}{$\begin{array}{c}\mathbf{Z D} \\
\% \\
\end{array}$} \\
\hline & $\mathrm{f}$ & $\%$ & $\mathrm{f}$ & $\%$ & $f$ & $\%$ & $\mathrm{f}$ & $\%$ & \\
\hline Natural numbers & 117 & 97,5 & 3 & 2,5 & 0 & 0 & 0 & 0 & 2,5 \\
\hline $\begin{array}{c}\text { Addition of natural } \\
\text { number }\end{array}$ & 117 & 97,5 & 3 & 2,5 & 0 & 0 & 0 & 0 & 2,5 \\
\hline $\begin{array}{c}\text { Subtraction of natural } \\
\text { number }\end{array}$ & 117 & 97,5 & 3 & 2,5 & 0 & 0 & 0 & 0 & 2,5 \\
\hline $\begin{array}{c}\text { Multiplication of natural } \\
\text { number }\end{array}$ & 56 & 46,6 & 57 & 47,5 & 7 & 5,8 & 0 & 0 & 53,3 \\
\hline $\begin{array}{c}\begin{array}{c}\text { Division of natural } \\
\text { number }\end{array} \\
\end{array}$ & 19 & 15,8 & 53 & 44,1 & 48 & 40 & 0 & 0 & 84,1 \\
\hline Fractions & 18 & 15 & 45 & 37,5 & 54 & 45 & 3 & 2,5 & 84,6 \\
\hline Fraction Operations & 9 & 7,5 & 48 & 40 & 60 & 50 & 3 & 2,5 & 92,3 \\
\hline
\end{tabular}

Table 3. Difficulty Percentages in the Views of the Pre-service Classroom Teachers related to the Geometry SLF

\begin{tabular}{|c|c|c|c|c|c|c|c|c|c|}
\hline \multirow{2}{*}{ SLF } & \multicolumn{2}{|c|}{$\mathbf{A}$} & \multicolumn{2}{c|}{ B } & \multicolumn{2}{c|}{ C } & \multicolumn{2}{c|}{ D } & ZD \\
\cline { 2 - 10 } & $\mathrm{f}$ & $\%$ & $\mathrm{~F}$ & $\%$ & $\mathrm{f}$ & $\%$ & $\mathrm{f}$ & $\%$ & $\%$ \\
\hline $\begin{array}{c}\text { Geometric figures } \\
\text { and objects }\end{array}$ & 87 & 72,5 & 30 & 25 & 0 & 0 & 3 & 2,5 & 25,6 \\
\hline Spatial relationships & 31 & 25,8 & 44 & 36,6 & 15 & 12,5 & 30 & 2,5 & 65,5 \\
\hline Geometric patterns & 51 & 42,5 & 60 & 50 & 6 & 5 & 3 & 2,5 & 56,4 \\
\hline $\begin{array}{c}\text { Basic concepts in } \\
\text { geometry }\end{array}$ & 66 & 55 & 48 & 40 & 6 & 5 & 0 & 0 & 45 \\
\hline
\end{tabular}

Table 4. Difficulty Percentages in the Views of the Pre-service Classroom Teachers related to the Measurement SLF

\begin{tabular}{|c|c|c|c|c|c|c|c|c|c|}
\hline \multirow{2}{*}{ SLF } & \multicolumn{2}{|c|}{$\mathbf{A}$} & \multicolumn{2}{c|}{ B } & \multicolumn{2}{|c|}{ C } & \multicolumn{2}{c|}{ D } & ZD \\
\cline { 2 - 11 } & $\mathrm{f}$ & $\%$ & $\mathrm{~F}$ & $\%$ & $\mathrm{f}$ & $\%$ & $\mathrm{f}$ & $\%$ & $\%$ \\
\hline Length Measurement & 72 & 60 & 36 & 30 & 12 & 10 & 0 & 0 & 40 \\
\hline Perimetry & 75 & 62,5 & 29 & 24,1 & 13 & 10,8 & 3 & 2,5 & 35,8 \\
\hline Square Measurement & 18 & 15 & 57 & 47,5 & 39 & 32,5 & 6 & 5 & 57,8 \\
\hline Our money & 112 & 93,3 & 4 & 3,3 & 1 & 0,8 & 3 & 2,5 & 4,27 \\
\hline Time Measurement & 87 & 72,5 & 24 & 20 & 6 & 5 & 3 & 2,5 & 25,6 \\
\hline Weighing & 89 & 74,1 & 22 & 18,3 & 6 & 5 & 3 & 2,5 & 23,9 \\
\hline Liquid Measurement & 55 & 45,8 & 50 & 41,6 & 12 & 10 & 3 & 2,5 & 52,9 \\
\hline
\end{tabular}

Table 5. Difficulty Percentages in the Views of the Pre-service Classroom Teachers related to the Data Field SLF

\begin{tabular}{|c|c|c|c|c|c|c|c|c|c|}
\hline \multirow{2}{*}{ SLF } & \multicolumn{2}{|c|}{ A } & \multicolumn{2}{c|}{ B } & \multicolumn{2}{c|}{ C } & \multicolumn{2}{c|}{ D } & ZD \\
\cline { 2 - 11 } & $\mathrm{f}$ & $\%$ & $\mathrm{~F}$ & $\%$ & $\mathrm{f}$ & $\%$ & $\mathrm{f}$ & $\%$ & $\%$ \\
\hline Data Processing & 87 & 72,5 & 20 & 16,6 & 1 & 0,8 & 12 & 10 & 19,4 \\
\hline
\end{tabular}


As it can be seen in Table 5, the item difficulty index of the data processing sub-learning field is below $20 \%$.

As it can be seen in Table 6, as a result of the interviews with the pre-service classroom teachers, it was determined that only the $9.16 \%$ of mathematics passing grade of the per-service teachers is AA, and $51.6 \%$ of them is below CC. They are already aware of the fact that this will be reflected on their students when they start teaching. The pre-service teachers stated that the subjects they perceive difficult is actually based on their lack of skills and knowledge in mathematics. The question "How would you teach mathematics to the elementary school 1 st grade pupils?" was asked to the pre-service teachers whose mathematics grade was the lowest. The pre-service teacher responded to this question as "I'm not quite sure because I don't know mathematics, either. I got into this department without answering any mathematics questions." It can be understood from this respond that the pre-service teachers who lack of mathematics knowledge and skills cannot teach mathematics.

Table 6. Passing Grade Percentages of the Pre-service Classroom Teachers

\begin{tabular}{|c|c|c|}
\hline Letter Grade & $\mathrm{f}$ & $\%$ \\
\hline AA & 11 & 9,16 \\
\hline BA & 10 & 8,3 \\
\hline BB & 3 & 2,5 \\
\hline CB & 7 & 5,8 \\
\hline CC & 27 & 22.5 \\
\hline DC & 13 & 10,8 \\
\hline DD & 18 & 15 \\
\hline FD & 12 & 10 \\
\hline FF & 17 & 14,1 \\
\hline D2 & 2 & 1,6 \\
\hline
\end{tabular}

\section{Results and Discussion}

In this study, the subjects that the pre-service classroom teachers have difficulty in 1-4 grade mathematics classes were determined according to the views of them. As a result of the study, it was determined that the pre-service teachers have difficulty in multiplication and division in natural numbers, fractions, fraction operations, square measurement and liquid measurement subjects among the sub-learning fields in the 1-4 grade mathematics curriculum. In the interviews, the reason why the pre-service teachers have difficulty in teaching multiplication is their lack of practice, which they think they cannot simplify the subjects to the student level, and that they will have difficulty in embodying the subject. Although this finding contradicts with the finding that pupils can do multiplication stated by Carpenter and colleagues [19] and Mulligan [20], it is supported with the finding of the studies by Rees and Barr [21] and Burns [22] that multiplication is considered to be boring and complicated by small pupils so that they can have difficulty in the questions that require multiplication.

Among the most challenging topics for pre-service teachers is the division in natural numbers, and they expressed the reason why they have difficulty in teaching it is their lack of practice, that they won't be able to simplify the subjects to the student level and they will have difficulty in embodying the subject, and in addition to these, they stated that teaching digits in division is difficult, particularly, they cannot embody the subject while teaching it. In the studies conducted with pre-service classroom teachers and classroom teachers in Australia and the USA [23,24], it was determined that beside they have difficulty in understanding the operations according to numbers and digit value, they are inadequate in the operations they operate by the book and in explaining the mathematical meaning of the operations. Similarly, it was determined in this study that the pre-service teachers have difficulty in teaching the division.

It was determined that the readiness level of the pre-service teachers studying in classroom teaching is insufficient in mathematics subjects. Findings are parallel with this study. This indicates that pre-service classroom teachers do not learn enough about elementary mathematics and that students who study in the university are challenged in the sub-learning fields of mathematics. However, it was determined that the most difficult subjects in these fields are operations in fractions, fractions, division in natural numbers and square measurement sub-learning fields. The pre-service teachers stated that the reason why they have difficulty in fractions is that the students meet with this subject for the first time so that they will have difficulty in comprehending it, that the subjects are interrelated and studying is not enough for success, that reasoning is required, that the operations take time, that part-whole concepts are not reinforced in the students, and that they have difficulty in terms of time in reinforcing the subjects. In addition, pre-service teachers stated that they also have difficulties in fraction operations themselves, so they will have difficulty in teaching them to the students. As the part-whole meaning is the basis of the four meanings of the rest of the fractions [25], it can be concluded that the student does not fully understand the concept of fractions, which coincides with the results in this study.

Both as a result of this study and of study by Duatepe [26], it can be said that geometry is one of the most challenging sub-learning fields of mathematics. The reason for this may be the shortcomings in the learning experiences presented to students from the past to present.

When examining the opinions of the pre-service teachers regarding the subjects that are challenging for pre-service classroom teachers, it is emphasized that these difficulties that pre-service teachers experience are caused 
by their lack of mathematical knowledge. Their general mathematical grades support this notion. In addition to that, the reasons why they have difficulty are being unable to simplify the subjects to the student level and to embody the subjects, low readiness level of the students, various question types, subjects being interrelated, that memorizing and only studying is not enough for success, the need and the difficulty of memorizing many formulas, the necessity of reasoning, that the operations take time and having difficulty in terms of time in reinforcing the subjects Tall stated that there are different studies conducted to determine learning difficulties in mathematics and the reasons for these difficulties are inadequate understanding of the basic concepts in mathematics and the lack of expressing verbal problems in mathematical expressions and the lack of algebraic and geometric skills [27]. When the opinions of the pre-service classroom teachers are examined, it was determined that another reason why they have difficulty in teaching mathematics is that they do not know how to use the materials correctly and on the spot while teaching mathematics. This can be examined as a separate study.

\section{Recommendations}

1. The topics that pre-service teachers perceive as difficult should be emphasized a little bit more within mathematics education and school experience lessons in undergraduate programs, and these issues should be taken into account when preparing programs.

2. Implementing student-centered approaches in classrooms where students are active instead of teacher-centered learning for subjects that are challenging for pre-service classroom teachers in elementary mathematics teaching classes will help students learn more effectively by making the information they learn more meaningful and lasting.

3. In order to be easily applied by teachers in elementary school mathematics curriculum, materials that can be used in the learning environment such as activities, worksheets that are designed taking into consideration the contemporary learning approaches are needed. In this respect, priority should be given to these topics while developing materials for teaching elementary school 1-4 grade mathematics lessons.

4. Knowing the adequacy of the students about the subjects of the previous turn and determining the level of readiness before the topic is started to be taught will be helpful in determining the students' successes and conceptual misconceptions. For this reason, diagnostic tests should be used to evaluate the knowledge of the students about the subject before and after the subjects, and alternative assessment tools like concept maps and self-assessment forms should be used to detect misconceptions or to evaluate what they know. This will make it easier for the teacher to know how ready his students are for the next topic, and to take precautions if they have any misconceptions.

5. In mathematics lessons, embodying the abstract subjects, the visualization of the lessons and the use of materials reduce the difficulties in teaching the subjects and facilitate learning. Providing appropriate teaching environments in this way can be done more regularly and frequently in mathematics classes. For this reason, mathematics classes should be established in schools. The shortcomings of the pre-service classroom teachers should be practically eliminated in these classes.

6. And the most important thing is that certain criteria should be determined and be selective while allowing students into faculty of education.

In this study, the subjects that the pre-service classroom teachers have difficulty in teaching in elementary 1-4 grade mathematics lesson were determined according to their opinions.

In another study, research could be done on expectations of the pre-service teachers from education faculties to overcome these difficulties.

\section{REFERENCES}

[1] R. Gürbüz, Z. Toprak, H. Yapıc1, S. Doğan. Ortaöğretim matematik müfredatında zor olarak algılanan konular ve bunların nedenleri. Gaziantep Üniversitesi Sosyal Bilimler Dergisi, Vol.10, No.4, 1311-1323.

[2] Y. Soylu, C. Soylu. İlköğretim Beşinci Sınıf Öğrencilerinin Kesirler Konusundaki Öğrenme Güçlükleri: Kesirlerde Sıralama, Toplama, Çıkarma, Çarpma Ve Kesirlerle İlgili Problemler, Erzincan Eğitim Fakültesi Dergisi, Vol.7, No.2, 101-117.

[3] Milli Eğitim Bakanlığı. PISA 2015 Ulusal Raporu. Millî Eğitim Bakanlığı, Ölçme, Değerlendirme ve Sınav Hizmetleri Genel Müdürlüğü, Ankara, 2016.

[4] H. Gür, E. Korkmaz. İlköğretim 7. Sınıf Öğrencilerinin Problem Ortaya Atma Becerilerinin Belirlenmesi. Online available from http://www.matder.org.tr/index.php?option=com_content \&view $=$ article\&id $=61$

[5] D. O. Tall, M. R. Razali. Diagnosing students' difficulties in learning mathematics. International Journal of Mathematical Education in Science and Technology, Vol.24, No.2, 209-222.

[6] Y. Ersoy, K. Erbaş. Kassel Projesi Cebir Testinde Bir Grup 
Türk Öğrencinin Genel Başarısı ve Öğrenme Güçlükleri. İlköğretim-Online, Vol.4, No.1, 18-39.

[7] L. S. Shulman. Those who understand: Knowledge growth in teaching. Educational Researcher, Vol.15, No. 2, 4-14.

[8] L. S. Shulman. Knowledge and teaching: Foundations of the new reform. Harvard Educational Review, Vol.57, No. $1,1-23$.

[9] M. F. Özmantar, E. Bingölbali. Sınıf öğretmenleri ve matematiksel zorlukları. Gaziantep Üniversitesi Sosyal Bilimler Dergisi, Vol.8, No.2, 401-427.

[10] D. L. Ball. Research on teaching mathematics: Making subject-matter knowledge part of the equation. Advances in research on teaching, Vol.2, 1-47.

[11] D. L. Ball. The mathematical understandings that prospective teachers bring to teacher education. The Elementary School Journal, Vol.90, No.4, 449-466.

[12] Z. Toluk Uçar. Öğretmen adaylarının pedagojik içerik bilgisi: öğretimsel açıklamalar, Turkish Journal of Computer and Mathematics Education, Vol.2, No.2, 87-102.

[13] Y. Ersoy, H. Ardahan, H. “İlköğretim Okullarında Kesirlerin Öğretimi II: Tanıya Yönelik Etkinlikler Düzenleme. Online available from: http://www.matder.org.tr/index.php?option=com_content \&view=article\&id=64:ilkogretim-okullarinda-kesirlerin-og retimi-ii-taniya-yonelik-etkinlikler

[14] E. Tatar, R. Dikici. Matematik Eğitiminde Öğrenme Güçlükleri. Mustafa Kemal Üniversitesi Sosyal Bilimler Enstitüsü Dergisi, Vol.5, No.9, 183-193.

[15] L. Cohen, L. Manion, K. Morrison. Research Methods in Education. British Journal of Educational Studies, Vol.48 No.4, 446-446.

[16] A. H. Johnstone, N. A. Mahmoud. Isolating topics of high perceived difficulty in school biology, Journal of Biological Education, Vol.14, No.2, 163-166.

[17] M. Bahar, A. H. Johnstone, M. Hansell. Revisiting learning difficulties in biology, Journal of Biological Education, Vol.33, No.2, 84-86.
[18] A. Yıldırım, H. Șimșek. Sosyal Bilimlerde Nitel Araştırma Yöntemleri (5. bask1). Seçkin Yayıncılık, Ankara, 2005.

[19] T. P. Carpenter, E. Ansell, M. L. Franke, E. Fennema, L. Weisbeck. Models of problem solving: A study of kindergarten chil dren's problem-solving processes. Journal for Research in Mathematics Education, Vol.24, No.5 428-441.

[20] J. Mulligan, J. Watson. A developmental multimodal model for multiplication and division. Mathematics Education Research Journal, Vol.10, No.2, 61-86.

[21] R. Rees, G. Barr. Diagnosis and prescription in the classroom: Some common maths problems. Harper \& Rows, 1984.

[22] M. Burns. About teaching mathematics: A K-8 resource. Math Solutions Publications, Marilyn Burns Education Associates, Sausalito, 2000.

[23] B. Southwell, M. Penglase. Mathematical knowledge of pre-service primary teachers. Proceedings of the 29 th Conference of the International Group for the Psychology of Mathematics Education, Vol. 4, 209-216, 2005.

[24] E. Thanheiser. Preservice elementary school teachers' conceptions of multidigit whole numbers. Journal for Research in mathematics Education, Vol.40, No.3, 251-281.

[25] C. Y. Charalambous, D. Pitta-Pantazi. Revisiting a theoretical model on fractions: Implications for teaching and research. In Proceedings of the 29th Conference of the International Group for the Psychology of Mathematics Education, Vol. 2, 233-240, 2005.

[26] A. Duatepe. Van Hiele geometrik düșünme seviyeleri üzerine niteliksel bir araştırma. Fen Bilimleri Eğitimi Kongresinde sunulan bildiri, Hacettepe Üniversitesi, Ankara, 2000.

[27] D. Tall. Students' difficulties in calculus. In proceedings of working group, Vol. 3, 13-28, 1993. 